\title{
A SURVEY ON WEED MANAGEMENT IN DRY LENTIL FIELDS
}

\author{
PALA, F. \\ Department of Plant Protection, Faculty of Agriculture, Siirt University, Siirt, Turkey \\ (e-mail: firatpala@siirt.edu.tr; phone: +90-484-212-1111) \\ (Received 23 ${ }^{\text {rd }}$ Oct 2018; accepted $7^{\text {th }}$ Jan 2019)
}

\begin{abstract}
A questionnaire consisting of 20 questions about weed, herbicide, tillage and crop rotation was applied to 100 lentil farmers to determine the current state of a weed problem in lentil fields in 2016. Common weeds were determined charlock mustard (Sinapis arvensis L., 36\%), devil-on-all-sides (Ranunculus arvensis L., 16\%), cleavers (Galium aparine L., 11\%), makhobeli (Cephalaria syriaca L., $8 \%$ ), and knapweed (Centaurea depressa L., 8\%), respectively. The majority of participants used aclonifen (89\%) as a post-emergence to control broadleaf, besides, clethodim (26\%), haloxyfop-methylester $(17 \%)$, tepraloxydim (16\%), quizalofop p-ethyl (15\%), and fluazifop p-butyl (6\%) for grass, respectively, and as a total herbicide glyphosate $(4 \%)$ as well. But, respondents $(66 \%)$ stated that lentils had crop injury from aclonifen. Growers took into account the price (43\%), herbicides (38\%), weeds $(10 \%)$ and crop rotation $(9 \%)$ to choose herbicides. Managing weeds with hand-picked $(76 \%)$ were common in areas that did not use herbicides. Preventive measures were used such as crop rotation (61\%), late sowing (10\%), and deep tillage (4\%), furthermore, farmers planted wheat (91\%) and barley (9\%) as a preceding crop. In this study, dissatisfaction was determined by the efficacy and selectivity of aclonifen which is registered herbicide on lentils in Turkey. Lentils have a short stature, slow early-season growth rate, and open-canopy growth habit, which make them poor competitors with broadleaf weeds. So weed management in the early period such as pre-planting, pre-emergence or early post-emergence herbicides, and IMI herbicide-tolerant lentil varieties (Clearfield) have been investigated.
\end{abstract}

Keywords: lentils, mustard, aclonifen, crop rotation, late sowing, plow tillage

\section{Introduction}

Lentils (Lens culinaris Medik.), which is well-known as nutritious food, is one of the important crops cultivated in the cool season. It grows as an annual bushy leguminous plant typically $20-45 \mathrm{~cm}$ tall, which produces many small purse- shaped pods containing one to two lens-shaped seeds each (SPG, 2017). It is not only a rich source of improved nutrition for people but also provides nutritious straw for animals. Lentil contains about 11 per cent water, 25 percent protein and 60 percent carbohydrate. The important lentil growing countries of the world are India (18.00 million ha), Canada (12.17 million ha), Turkey (2.43 million ha), Iran (1.68 million ha), Australia (1.62 million ha), Bangladesh 1.24 (million ha), Syria (1.11 million ha), USA (1.04 million ha) respectively. Turkey ranks third in the world in respect of production as well as area followed by India and Canada (FAOSTAT, 2014). One-third of the country's production of lentil is provided by Diyarbakir province (TUIK, 2016).

Lentil production provides several agronomic advantages and opportunities to increase profit margins. Besides tolerating drought conditions, cool temperatures, and a wide variety of soil types, leguminous pulse crops can also help fix nitrogen in the soil. However, growers should be aware of the challenges and opportunities of managing weeds in these crops (Pala et al., 2018). The common problem is weeds in lentils widely cultivated such as Native red, Firat-87, Seyran-96, Cagil, Altintoprak and Sakar. Weed management in varieties is generally considered to be a poor competitor due to its slow establishment and limited vegetative growth. Their productivity is adversely affected by the presence of weeds (Swanton et al., 2015). Lentil yield loss from the competition 
with weeds can range as high as $80 \%$ (Beniwal and Dalkiran, 1995; Yenish et al., 2009). On the other hand, it is known that weeds host the sloe bug (Dolycoris baccarum L.) and gorse shieldbug (Piezodorus lituratus F.) that causing chalking problem on lentil (Akkaya, 2004; Ozberk et al., 2014). The prominent weed species infesting lentil crop are charlock mustard (Sinapis arvensis L.), field bindweed (Convolvulus arvensis L.), volunteer wheat (Triticum spp.), wild oat (Avena spp.), knapweed (Centaurea depressa M. Bieb), cow cockle (Vaccaria pyramidata), vetch (Vicia sp.), cleavers (Galium aparine), volunteer barley (Hordeum vulgare), pheasant's (Adonis aestivalis), fumitory (Fumaria officinalis L.) etc. (Guncan, 2014; Tepe, 2014; Kraehmer, 2016; Pala et al., 2018). The concept that high input provided for higher yield, also pose high risk, if weeds are not controlled.

Climate change and applied agricultural practices cause changes in the populations of harmful organisms (pests, pathogens, and weeds) that cause significant losses in crop plants (Flood, 2010; Ucak et al., 2017). Cultural practices to decrease weed pressure in lentil crops include prevention, seedbed preparation, variety selection, proper sowing and, crop establishment, insect and disease management. For example, Baird et al. (2009) observed that increasing the seeding density of lentil translated into increased yield and decreased weed biomass. However, while cultural practices such as allelopathy, cover crops, and crop rotations are at the backbone of integrated weed management (IWM) plan, they alone may not be enough to secure adequate weed control in lentil fields (Pala et al., 2018). In addition, cultivation of soil with smart sensitive cultivator, monitoring of plants and pests with a drone and local intervention, and the application of steam and soil disinfection on field crops, vegetables and fruits and the control of diseases, pests, and weeds should be investigated (Pala et al., 2017).

Mechanical weed control practices in lentil, such as harrowing or rotary hoeing fields in fall, after the emergence of weeds but before lentil planting. Also to control weeds generally hand weeding is in practice but it is now costly as well as difficult because of the non-availability of labor in peak periods (Bhan and Kukula, 1987). Crop rotation is one of the other powerful tools to manage weed problems. To high persistence herbicides commonly used in small grain crops such as iodosulfuron, metsulfuron, chlorsulfuron sulfosulfuron etc. can damage subsequent annual legumes, including lentil (Kraehmer, 2012; SPG, 2017). There are a number of herbicides registered to control grassy weeds in lentil, but few options exist for control of broadleaf weeds (Brand et al., 2007). To applicability and success of herbicides in lentil fields depend on the cropping system, land preparation methods, soil conditions, and weed problems. For example, challenge (aclonifen) is a selective herbicide that is in the diphenyl ether group, it is used for postemerge against broadleaf weed in lentils. When it applies at recommended rates provides effective control on some broadleaf weeds, but it is not effective enough some broad-leaved weeds or ineffective, in addition, it can cause crop damage in stressful conditions of cold weather, low fertility, disease, or insect damage. Also, although pursuit (imazethapyr) can be used to manage broadleaf weeds in no-till or minimum tillage systems, it has many application restrictions due to crop safety concerns, including leaf chlorosis, stand reduction, and decreased yields, especially cold and wet conditions occurring within a week of application can severely damage the crop (Friesen and Wall, 1986; Muehlbauer et al., 1995; Ghosheh and El-Shatnawi, 2003). These methods can be supported by other mechanical and cultural processes such as tillage, late sowing, and rotation (Kayan and Adak, 2006; Dogan, 2014). However, lentil is sensitive to weed competition. Weed growth reduces lentil yields by competing 
for light, moisture, and nutrients. It is known that available practices in the control of weeds in lentil fields are inadequate (Harper, 1977; Swanton et al., 2015). The USA and Canada developed lentil varieties tolerant to the imidazolinone (an acetolactate synthase [ALS]-inhibitor) herbicides through mutation breeding in order to deal with the shortcomings in broadleaf weed control in lentil (Chant, 2004; Slinkard et al., 2007). Weed control in these ALS inhibitor herbicide-tolerant lentil varieties was initially excellent and, as a consequence, they have had very high adoption rates. Hence lentil is a suitable model crop to study on weeds and weed management due to the limitations of weed control for this crop.

In order to develop economic, effective and environmentally friendly IWM tactics in lentil, where weed competition is weak, it is necessary to monitor the distribution and the prevalence of weed species which are primarily a problem. There have been a limited number of studies on weed species in our country and in our province, but no detailed and up-to-date studies have been found. With this view, the study has undertaken the determination of existing weed control techniques in lentil fields.

\section{Material and methods}

The survey was conducted in Diyarbakir where it is located in the Southeastern Anatolia Region (SAR) of Turkey in spring 2016 (Fig. 1). Lentil is mainly grown in the non-irrigated areas.

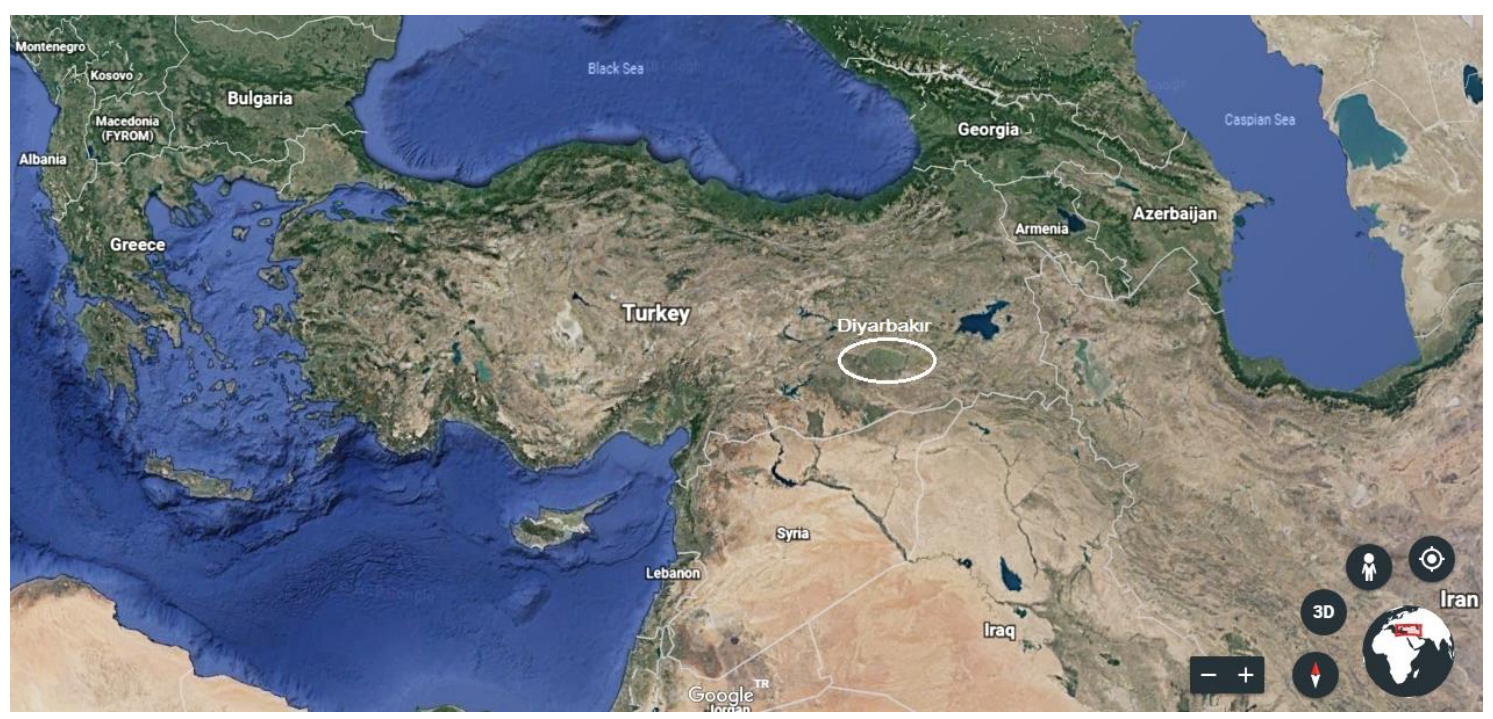

Figure 1. Location of surveys, Diyarbakir Turkey

The most lentil growing districts, cultivated fields and sample number are given in Table 1 .

The surveys were carried out in the Bismil, Cermik, Cinar, Dicle, Egil, Ergani, Hani, Hazro, Kayapinar, Silvan, and Sur. Sampling size and the settlements of the interviews were determined purposively according to the Turkish Statistical Institute (TUIK) database. In this regard, 100 farm enterprises were determined and interviewed to represent the study area. A questionnaire containing questions regarding a) common weeds agronomic practices including tillage, irrigation, crop rotation, fertilization, 
harvesting b) weed management practices, c) problematic weed rankings, d) knowledge of weed management and e) efficiency of extension services; was prepared and each grower was interviewed for answering the questionnaire. Using the proportional sample volume formula (Eq. 1) (Newbold, 1995).

$$
n=\frac{N \cdot p(1-p)}{(N-1) \sigma_{p x}^{2}+p(1-p)}
$$

The formula; $\sigma_{p x}^{2}=$ Variance of rate (90\% confidence interval and 5\% 5\% tolerance), $\mathrm{n}$ : Sample volume, N: The main mass represents. p: rate (p: 0.5 ). The data collected during the survey were analyzed by using frequencies and simple percentages.

Table 1. Districts surveyed in Diyarbakir province and number of samples taken (TUIK, 2016)

\begin{tabular}{c|c|c}
\hline Districts & Lentils field $(\mathbf{h a})^{*}$ & The number of participants \\
\hline Bismil & 24.580 & 48 \\
Cermik & 1.700 & 16 \\
Cinar & 3.350 & 12 \\
Dicle & 600 & 10 \\
Egil & 411 & 6 \\
Ergani & 5.500 & 3 \\
Hani & 521 & 1 \\
Hazro & 450 & 1 \\
Kayapinar & 800 & 1 \\
Silvan & 9.000 & 1 \\
Sur & 6.500 & 1 \\
\hline Total & $\mathbf{5 3 . 4 1 2}$ & $\mathbf{1 0 0}$ \\
\hline
\end{tabular}

\section{Results and discussion}

The outcome of the survey two out of three of the participants in the survey was between 30-50 years of age. Approximate half of them had education up to primary school and one-third of them had a secondary school. This shows the education level was low and a very small portion of respondents had higher graduate degrees. The farmers were asked; since how long you have been grown lentil. Response was 1-10, 10-20, 20-30 and $>30$ years which ranged 19, 28, 45, and 8 respectively. The area of lentil production was $<5,5-10,10-20,20-50$, $>50$ ha with percentages of $9,38,35,12$, and $6 \%$ respectively. This value showed that tw- thirds of the farmers produce lentil in the fields between 10 and 50 ha.

The preceding crops of lentil are wheat $91 \%$ and barley $9 \%$ (Table 2). The results of the survey showed that all of the farmers planted cereal before lentil production. Crop rotation strongly affects the density and composition of weed flora because the different crops in rotation require different agricultural practices and herbicide. Due to continuously changing agricultural practices as a result of crop rotation; the adaptation's success of certain species to a specific area under sole or mono-cropping could be prevented (Kayan and Adak, 2006; Erman et al., 2008; Dogan, 2014). Tepe et al. (2004) 
reported that crop rotation is an important part of a good weed control program in lentil agriculture. Certain weeds, especially broadleaf weeds in lentil, may be less difficult to control in a farming system having preceding crops such as cereal. Other benefits of crop rotation may include a reduction in insects, diseases and nematode problems in lentil.

Table 2. The preceding crops of lentil grown by farmers in survey

\begin{tabular}{c|c}
\hline Preceding crop & Percentage (\%) \\
\hline Wheat & 91 \\
Barley & 9 \\
Total & $\mathbf{1 0 0}$ \\
\hline
\end{tabular}

When the respondents were asked for the tillage practices being used by them in lentil agriculture, $12 \%$ of respondents stated that the tillage practices included the plow in autumn, and $88 \%$ cultivator and harrow tillage before planting. Planting with the seeders/planters system is opted by the growers in the region. The $87 \%$ of respondents stated that they planted seeds after the rain due to moisture, and the rest before the rain in dry soil. When asked the effect of tillage systems on weed density, $76 \%$ of respondents stated that deep plowing reduces weed density. When asked for previous crop residue, the majority of respondents answered that they burned them usually. Previous crop residue and tillage practices can affect weed population dynamics, including weed seed distribution and abundance in the soil seed bank (Mulugeta and Stoltenberg, 1997). There are reports that weed control was improved by using plow for tillage (Durutan et al., 1989; Pala et al., 2000; Camara et al., 2003). When asked for irrigation and fertilization, $100 \%$ of respondents answered that they did not use both of them in lentil production. This crop produces a dry climate and does not need to use fertilizer in Diyarbakir. The most problematic weed species in the lentil field are represented in Table 3. Sinapis arvensis L. as a broadleaf, and Avena fatua L. as a grass were the first most problematic weeds, respectively. In the study carried out, important weed species found in the lentil fields were adapted to the agricultural products in winter and spread especially in these fields. For this reason, these species, which are found in the field of surveillance, are among the important weeds, which are problematic both in countries such as Canada and India, and in beans and pulses in our country (Holm et al., 1977; Guncan, 2014; Tepe, 2014; Kraehmer, 2016; SPG, 2017). So, this shows that the problematic weed species stated by farmers are similar to the majority of species reported in the lentil fields.

Weeds emerging in lentil fields and trouble for farmers are mostly broadleaves such as $S$. arvensis, $R$. Arvensis, and $G$. aparine. Majority of participants stated they combined tillage, hand-picking, and herbicides commonly. $89 \%$ of them used to control broadleaf weeds by using aclonifen as a chemical broadleaf weeds control method (Table 4). Hand-picking (76\%) was common in areas that do not use herbicides. Guncan (2014) stated that fewer herbicides are available for use in lentil. It is known just there is just one registered herbicide for broadleaf weeds in the lentil fields of Turkey.

Participants used clethodim, haloxyfop-methyl-ester tepraloxydim, quizalofop pethyl, fluazifop p-butyl for grass ratios $26,17,16,15,6 \%$, respectively (Table 5). But, $66 \%$ of aclonifen reported phytotoxicity, also few farmers (4\%) applied glyphosate, preemergence. 
Table 3. According to participants noxious weeds in lentil fields

\begin{tabular}{c|c}
\hline Weed species & Percentage (\%) \\
\hline Sinapis arvensis $\mathrm{L}$. & 36 \\
Ranunculus arvensis $\mathrm{L}$. & 16 \\
Galium aparine $\mathrm{L}$. & 11 \\
Cephalaria syriaca $\mathrm{L}$. & 8 \\
Centaurea depressa $\mathrm{L}$. & 8 \\
Avena fatua $\mathrm{L}$. & 7 \\
Vicia sativa $\mathrm{L}$ & 6 \\
Adonis aestivalis $\mathrm{L}$. & 3 \\
Vaccaria pyramidata Medik. & 3 \\
Fumaria officinalis $\mathrm{L}$. & 1 \\
Triticum aestivum $\mathrm{L}$ & 1 \\
Total & $\mathbf{1 0 0}$ \\
\hline
\end{tabular}

Table 4. Herbicides used to control broadleaf weeds in lentil fields

\begin{tabular}{c|c}
\hline Herbicides for broadleaf & Percentage (\%) \\
\hline Aclonifen* & 89 \\
No chemical** & 11 \\
Total & $\mathbf{1 0 0}$ \\
\hline
\end{tabular}

*Post-emergence for broadleaf. **Hand-picking

Table 5. Herbicides used to control grass weeds in lentil fields

\begin{tabular}{c|c}
\hline Herbicides for grass & Percentage (\%) \\
\hline Clethodim* & 26 \\
Haloxyfop* & 17 \\
Tepraloxydim* & 16 \\
Quizalofop* & 15 \\
Fluazifop* & 6 \\
No chemical** & 20 \\
Total & $\mathbf{1 0 0}$ \\
\hline
\end{tabular}

*Post-emergence for grass. **Hand-picking

The preventive measures were used in lentil fields by farmers such as crop rotation, late planting, deep tillage in order of $61,10,4 \%$ (Table 6 ).

Participants took into account the price (43\%), herbicides $(38 \%)$, weeds $(10 \%)$ and crop rotation (9\%) to choice weed management in the survey, respectively (Table 7).

Lentil has an early-season slow growth and open-canopy growth habit, which makes them poor competitors with weeds, so the control of weeds in the early period is too important. But we do not have much of a pre-plant, pre-emergence or post-emergence herbicide choice, especially to control of the broadleaf weeds emerging in lentil fields. Also, there is dissatisfaction with the efficacy and selectivity of aclonifen, the only registered herbicide in Turkey. This survey emphasizes the need to define the effects of 
weeds in lentil fields and to understand the effects of management on weed populations. It is essential to control weeds as tillage pre-plant, and herbicides post-plant are used in lentil production areas. Weed management systems significantly affect weed control and yield crops. Therefore, weed management in lentil has been a major challenge for crop producers from the start of agriculture.

Table 6. Preventive measures and mechanical applications against weeds in lentil

\begin{tabular}{c|c}
\hline Cultural measures and tillage & Percentage $(\boldsymbol{\%})$ \\
\hline Crop rotation & 61 \\
Late sowing & 10 \\
Plow tillage & 4 \\
Others* & 25 \\
Total & $\mathbf{1 0 0}$ \\
\hline
\end{tabular}

*Varieties, roller, more seeds, intra-row etc.

Weeds compete for factors such, nutrients, water and light, also some weeds host many plant pathogens and insects harmful to lentil, preventing certain agricultural practices in a fit and rapid manner. It was important that cultural measures (crop rotation with $61 \%$ and late sowing with $10 \%$ ) were the first choice for preventing weeds from damaging lentil yield and quality.

Table 7. Considerations when choosing methods for controlling weeds

\begin{tabular}{c|c}
\hline The matters considerations & Percentage (\%) \\
\hline Price & 43 \\
Herbicide diversity & 38 \\
Weeds & 10 \\
Crop rotation & 9 \\
Total & $\mathbf{1 0 0}$ \\
\hline
\end{tabular}

The fluctuations in labor, fuel and herbicide prices from year to year caused the input cost (price 43\%) to be the main concern of farmers when deciding on weed control. In order to carry out economic analyzes in an appropriate way, it was understood that current studies on critical period and economic threshold were needed.

\section{Conclusions}

The available major agricultural issues are to feed the world without contaminating the environment. Weeds are the most important constraints in lentil production. Despite the fact that cereals are planted as previous crops, the fact that grains are not mentioned by farmers as a major weed problem is related to the destruction of grains by tillage and late sowing of lentils. The fact that weeds are problematic in the lentil production areas of the weeds expressed as a problem indicates that the farmers recognize weeds. Farmers complained that the market is not enough herbicides for broadleaf weeds control unlike the herbicides used in the control for grasses. It is good but insufficient to make crop rotation by little more than half of the farmers. It is also observed that the late tillage and plow deep tillage are not aware of the importance of weed control by 
participants. While the method of weed control is chosen in lentil fields, firstly, the low cost and the availability of herbicides determine the behavior of farmers. As a result, the survey showed weeds, which are expressed as a problem in lentil fields by participants, have been the common weeds that cause significant yield losses in lentils and showed that the cultural measures, mechanical and chemical weed control are insufficient. To this end, herbicides are used to control weeds; however, overconfidence on herbicides is not sustainable in the long run. Therefore, there is a need to develop integrated weed management strategies in the lentil production systems, which aim to reduce the weed seed bank before lentil sowing and reduce weed emergence and weed growth in lentils. It was shown that weed management practices are inadequate in lentil fields. So new tactics should be improved such as imidazolinone (IMI) tolerant non-transgenic crops called Clearfield lentil varieties by ethyl methanesulfonate (EMS) which is a mutagenic, teratogenic, and possibly carcinogenic organic compound.

\section{REFERENCES}

[1] Akkaya, A., 2004. The studies of chalky spot factors causing yield and quality loss on red lentil and their control possibilities in Southeastern Anatolia Region. Plant Protection Research Institute, Diyarbakir, Turkey.

[2] Baird, J., Shirtliffe, S., Walley, F. (2009): Optimal seeding rate for organic production of lentil in the northern Great Plains. - Can J Plant Sci 89: 455-464.

[3] Beniwal, S. P. S., Kaiser, W. J., Dalkiran, H. (1995): Biotic Constraints to the Production of Lentils and Their Management in the Highlands of West Asia and North Africa. - Ed. J. D. H. Keating and I Kusmenoglu, Ankara.

[4] Bhan, V. M., Kukula, S. (1987): Weed and their control in chickpea (Cicer arietinum L.). - CAB International, Wallingford, Oxon, pp. 319-328.

[5] Brand, J., Yaduraju, N. T., Shivakumar, B. G., McMurray, L. (2007): Weed Management. - In: Yadav, S. S., McNeil, D. L., Stevenson, P. C. (eds.) Lentil-An Ancient Crop for Modern Times. Springer, Dordrecht, pp. 159-172.

[6] Camara, K. M., Payne, W. A., Rasmussen, P. E. (2003): Long-term effect of tillage, nitrogen and rainfall on winter wheat yields in the Pacific Northwest. - Agron J. 95: 828835 .

[7] Chant, S. R. (2004): Imidazolinone tolerance in lentil (Lens culinaris Medik.). - M.Sc. Thesis. University of Saskatchewan, Saskatoon, SK, Canada.

[8] Dogan, Y., Togay, T., Togay, A. (2014): Effect of different sowing time on yield and yield components of lentil (Lens culinaris Medic.) varieties in Mardin Kiziltepe conditions. - Journal of Tekirdag Agricultural Faculty 11(2): 51-58.

[9] Durutan, N., Guler, M., Karaca, M., Meyveci, K., Avcin, A., Eyuboglu, H. (1989): Effect of various components of the management package on weed control in dryland agriculture. - In: Soil and Crop Management of Improved Water Use Efficiency in Rainfed Areas. Proceedings of an International Workshop, Ankara, Turkey.

[10] Erman, M., Tepe, I., Bukun, B., Yergin, R., Taskesen, M. (2008): Critical period of weed control in winter lentil under non-irrigated conditions in Turkey. - African Journal of Agricultural Research 3(8): 523-530.

[11] FAOSTAT (2014): Food and Agriculture Organization of the United Nations. http://www.fao.org/faostat/en/\#home.

[12] Flood J: The importance of plant health to food security. Food Secur., 2(3): 215-231.

[13] Friesen, G. H., Wall, D. A. (1986): Tolerance of lentil (Lens culinaris Medik.) to herbicides. - Can J Plant Sci 66: 131-139. 
[14] Ghosheh, H. Z., El-Shatnawi, M. K. (2003): Broadleaf weed control in chickpeas (Cicer arietinum), faba beans (Vicia faba) and lentils (Lens culinaris). - Acta Agron Hungarica 51: 427-444.

[15] Guncan, A. (2014): Weed Management. - Selcuk University Publisher, Konya.

[16] Harper, J. L. (1977): The Population Biology of Plants. - Academic Press, London.

[17] Holm, L. G., Plucknett, D. L., Pancho, J. V., Herberger, J. P. (1977): The World's Worst Weeds, Distribution and Biology. - East-West Center University Press of Hawaii, Honolulu.

[18] Kayan, N., Adak, M. S. (2006): Effect of soil tillage and weed control methods on weed biomass and yield of lentil (Lens culinaris Medic.). - Agronomy and Soil Science 52(6): 697-704.

[19] Kraehmer, H. (2012): Innovation: changing trends in herbicide discovery. - Outlooks Pest Manag. 23: 115-118.

[20] Kraehmer, H. (2016): Atlas of Weed Mapping. - Wiley and Sons. Ltd., Chichester, pp. 87-104.

[21] Muehlbauer, F. J., Kaiser, W. J., Clement, S. L., Summerfield, R. J. (1995): Production and breeding of lentil. - Advances in Agronomy 54: 283-332.

[22] Mulugeta, D., Stoltenberg, D. E. (1997): Weed and seedbank management with integrated methods as influenced by tillage. - Weed Sci. 45: 706-715.

[23] Newbold, P. (1995): Statistics for Business and Economics. - Prentice Hall Inc., Upper Saddle River, NJ.

[24] Ozberk, İ., Tanrikulu, O. M. (2014): A study on some grading factors affecting marketing price of red lentil (L. culinaris Medik.) in South-East Anatolia. - Journal of Field Crops Central Research Institute 23(1): 1-6.

[25] Pala, F., Mennan, H., Demir, A. (2017): Investigation of problems and considerations on weed control methods in field crops of Diyarbakir. - International Conference on Multidisciplinary, Science, Engineering and Technology, Bitlis, Turkey.

[26] Pala, F., Mennan, H., Demir, A., Ocal, A., Karipcin, M. Z., Pakyurek, M., Aydin, M. H. (2017): Effect on weed control of soil disinfection with steam in strawberry farms. - 4th International Regional Development Conference, Malatya, Turkey.

[27] Pala, F., Mennan, H., Demir, A. (2018): Determination of the weed species, frequency and density in lentil fields in Diyarbakir province. - Turkish Journal of Weed Science 21(1): 33-42.

[28] Slinkard, A., Vandenberg, A., Holm, F. (2007): Lentil plants having increased resistance to imidazolinone herbicides. - US Patent 7,232,942 B2.

[29] SPG (2017): Saskatchewan pulse growers. - http://saskpulse.com/growing/lentils/.

[30] Swanton, C. J., Nkoa, R., Blackshaw, R. E. (2015): Experimental methods for crop weed competition studies. - Weed Sci. 63(1): 2-11.

[31] Tepe, I. (2014): Weed Management. - Sidas Medya Agriculture Publisher No: 31, Izmir, Turkey.

[32] Tepe, I., Erman, M., Yazlik, A., Levent, R., Ipek, K. (2004): Effect of different control methods on weeds, yield components and nodulation in the spring lentil. - Turk J. Agric. For. 28: 49-56.

[33] TUIK (2016): Turkish Statictical Institute. - http://www.turkstat.gov.tr/Start.do.

[34] Ucak, A. B., Kaplan, C., Inal, B., Gencoglan, S. (2017): Effects of different irrigation levels on mediterranean corn borer (Sesamia nonagrioides Lefebvre) populations and effects of fatty acids in corn borer preferences. Fresenius Environmental Bulletin, 26(12A): 8211-8220.

[35] Yenish, J. P., Larsen, R., Pala, M., Haddad, A. (2009): Weed Management. - In: Erskin, W., Meuhlbauer, F. J., Sarker, A., Sharma, B. (eds.) The Lentil Botany, Production and Uses. CABI, Oxfordshire, UK. 